\title{
Staphylococcal Scalded Skin Syndrome in a Child with Acute Lymphocytic Leukemia
}

\section{Akut Lenfositik Lösemili Bir Çocuk Olguda Stafilokoksik Haşlanmış Deri Sendromu}

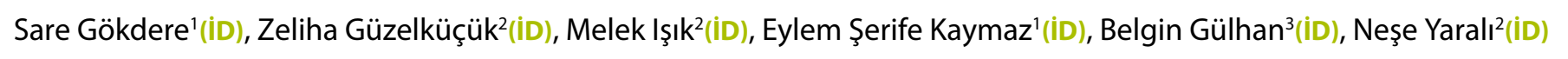 \\ ${ }^{1}$ Clinic of Pediatrics, Health Sciences University Ankara Children Health and Diseases Hematology Oncology Training and Research Hospital, Ankara, Turkey \\ ${ }^{2}$ Clinic of Pediatric Hematology and Oncology, Health Sciences University Ankara Children Health and Diseases Hematology Oncology Training and \\ Research Hospital, Ankara, Turkey \\ ${ }^{3}$ Clinic of Pediatric Infectious Diseases, Health Sciences University Ankara Children Health and Diseases Hematology Oncology Training and Research \\ Hospital, Ankara, Turkey
}

Cite this article as: Gökdere S, Güzelküçük Z, Işık M, Kaymaz EŞ, Gülhan B, Yaralı N. Staphylococcal scalded skin syndrome in a child with acute lymphocytic leukemia. J Pediatr Inf 2019;13(4):e180-e182.

\section{Abstract}

Staphylococcal scalded skin syndrome (SSSS) is a disease caused by the exfoliative toxin of Staphylococcus aureus. There is an overall incidence of SSSS between 0.09 and 0.13 cases per 1 million inhabitants annually. The accurate incidence of SSSS in immune deficient population is not known, and it is supposed that it is very rare; only a few case reports particularly in adult patients have been reported. In this study, we present a patient with a diagnosis of acute lymphocytic leukemia who developed SSSS after suppurative otitis media during febrile neutropenia attack.

Keywords: Staphylococcal scalded skin syndrome, neutropenic fever, acute lymphocytic leukemia

\section{Introduction}

Staphylococcal scalded skin syndrome (SSSS) is a disease caused by the exfoliative toxin of Staphylococcus aureus (1). There is an overall incidence of SSSS between 0.09 and 0.13 cases per 1 million inhabitants annually (2). The accurate incidence of SSSS in immune deficient population is not known, and it is supposed that it is very rare; only a few case reports particularly in adult patients have been reported (3).

Here, we report a child with acute lymphocytic leukemia (ALL) who developed SSSS after suppurative otitis media infection during a febrile neutropenia attack.
Öz

Stafilokoksik haşlanmış deri sendromu (SHDS) Staphylococcus aureus eksfolyatif toksininın yol açtığı nadir bir hastalıktır. İnsidansı yılda bir milyonda 0.09 ila 0.13 arasında değişmektedir. İmmünyetmezlikli bireylerdeki insidansı ise bilinmemektedir ancak çok nadir olduğu tahmin edilebilir. Bu konuda yetişkin hastalarda çok az olgu bildirilmiştir. Bu yazıda, febril nötropeni atağı sırasında süpüratif otitis media sonrası SHDS gelişen akut lenfositik lösemi tanılı bir çocuk hasta sunulmuştur.

Anahtar Kelimeler: Stafilokoksik haşlanmış deri sendromu, nötropenik ateş, akut lenfositik lösemi

\section{Case Report}

A 4-year-old boy diagnosed with high risk (BCR/ABL positive) ALL was admitted to our hematology clinic with ear pain while receiving ALL-IC BFM 2009 reinduction treatment including dexamethasone, doxorubicin, L-asparaginase and imatinib and secondary fungal prophylaxis with voriconazole. He was afebrile but had mild respiratory symptoms such as rhinorrhea. His physical examination was normal except redness and bulging of tympanic membrane on his otoscopic examination. He was hospitalized, and $150 \mathrm{mg} / \mathrm{kg}$ dose of sulbactam-ampicillin was started and chemotherapy protocol was continued. 
Two days later though, he was neutropenic with white blood cell as $200 / \mu \mathrm{L}$, absolute neutrophil count as $100 / \mu \mathrm{L}$. He was still afebrile, and otorrhea occurred. CRP level raised to $35 \mathrm{mg} / \mathrm{dL}$ (range $0.1-0.8 \mathrm{mg} / \mathrm{dL}$ ), and he was accepted as febrile neutropenic and antibiotherapy was changed to piperacillin-tazobactam. Ear discharge, peripheral blood and catheter cultures were obtained. Chemotherapy protocol was skipped, and topical ear drops of ciprofloxacin and dexamethasone where added to the therapy. Although blood and catheter cultures were negative, S. aureus was identified at his ear discharge culture, which was sensitive to most antibiotics, and the therapy of piperacillin-tazobactam was continued. On $6^{\text {th }}$ day, otorrhea and otalgia endured and his temperature increased to $40^{\circ} \mathrm{C}$; temporal bone and thorax computerized tomography scan was performed and bilateral mastoiditis and pneumonic consolidation on the left lung lower lobe was demonstrated. Furthermore, a skin rash beginning from the toe and hand fingers that spread over the scalp, hand and joint locations like the axilla, inguinal and cubital area occurred (Figure 1). The rash was red and flaccid blistering and looked like scalded skin. Due to the progressive worsening of his condition, the antibiotics were modified to meropenem, vancomycin and liposomal amphotericin. Supportive therapy with intravenous immunoglobulin and granulocyte transfusions was also given. With this therapy, skin lesions and symptoms got better day-by-day. After using meropenem and vancomycin for 21 days, the patient's symptoms regressed.

\section{Discussion}

In patients with neutropenic fever, the pathogenic organism varies from institute to institute (4). The most commonly identified microorganisms are gram-negative organisms such as Pseudomonas and Klebsiella but staphylococcal infection can also be life threatening in our clinic. Though coagulase negative staphylococcus is the predominant pathogen mostly identified in catheter cultures of our patients, $S$. aureus is an infrequent microorganism isolated in our febrile neutropenic patients (5).

Staphylococcus spp. cause both systemic and cutaneous infections, including impetigo, furuncle, subcutaneous abscess, SSSS, toxic shock syndrome (TSS) and neonatal toxic shock syndrome-like exanthematous disease (6). The incidence in pediatric and immunosuppressed patients is not clear, only a few cases have been reported in adult patients (3). Among multiple virulence factors, staphylococci secrete several exotoxins directly associated with particular disease symptoms including toxic shock syndrome toxin 1 (TSST-1), enterotoxins, and exfoliative toxins (ETs). The latter are particularly interesting as the sole agents responsible for SSSS. Exfoliative toxins induce the acantholytic effect of $S$. aureus due to the interruption of cell-tocell connection, which allows the pathogens to spread within the epithelium. Moreover, S. aureus expresses exotoxins act like superantigens that induce T-cell activation with subsequent energy and immunosuppression. Toxins are excreted by the

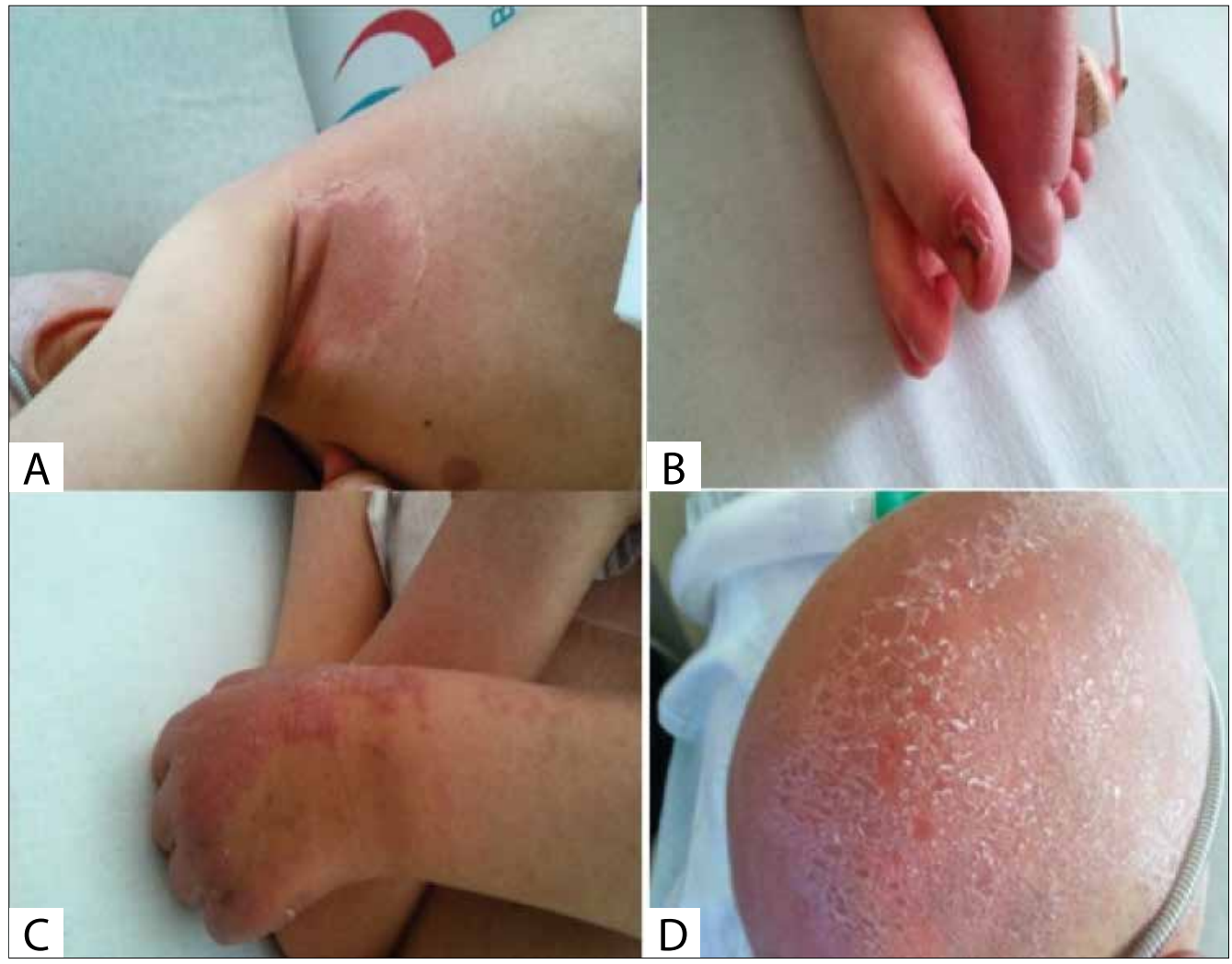

Figure 1. A: Skin rash on the axilla, B: Skin rash on the toe, C: Skin rash on the hand, D: Skin rash on the scalp. 
kidney, and children are more susceptible to SSSS because of immature renal clearance capability and lack of immunity. Important facilitating factors are neutropenia and decreased Tcell immunity caused by tchemotherapy. Our case also had these risk factors for SSSS (6-8).

Severity of SSSS varies from a few blisters limited to the site of infection to severe exfoliation affecting almost the whole body (8). Mortality rate in children is very low (1-5\%) unless associated sepsis or an underlying serious medical condition exists. Mortality rate in adults is higher (as high as $50-60 \%$ ) although it may be due to comorbid conditions, which increase susceptibility to SSSS (9). Complications are usually the result of sepsis, superinfection, and dehydration or electrolyte imbalance due to denuded skin. It should be kept in mind that it can be life threatening especially in immunocompromised patients $(6,10,11)$.

Differential diagnosis of SSSS is other blistering disorders such as toxic epidermal necrolysis (TEN) and Steven-Johnson Syndrome (SJS). They are rare but life-threatening mucocutaneous diseases that predominantly occur as adverse reactions to newly administered drugs. SJS/TEN risks are increased among patients with lupus erythematosus, recent pneumonia, or active malignancy mostly hematologic (12). SSSS can be differentiated from TEN/SJS by the lack of mucous membrane involvement as well as by more superficial epidermal peeling, which is in contrast to the full thickness denudation found in TEN and SJS. A skin biopsy can be required for the confirmation of diagnosis.

For localized SSSS forms without an underlying disease, the optimal treatment is oral antibiotics and local care. In patients with signs of systemic infection, intravenous antibiotics, topical wound care and appropriate fluid replacement is required (3). Our patient's general condition deteriorated and serious infection signs appeared. Therefore, combined broad-spectrum antibiotic therapy, fluid electrolyte support, and granulocyte suspension were used.

Bloodstream infections or bacterial endocarditis is the most common effected sites of gram-positive bacterial infections in patients with febrile neutropenia. SSSS should be kept in mind for the differential diagnosis of blistering lesions in patients with malignancy. Early and prompt diagnosis and treatment are essential for this mortal condition.
Informed Consent: Oral consent was obtained from the patients relatives.

Peer-review: Externally peer-reviewed.

Author Contributions: Concept - ZG, Ml; Design - ZG, EŞK; Supervision - NY; Writing - SG, ZG; Critical Review - BG.

Conflict of Interest: The authors have not reported a conflict of interest.

Financial Disclosure: There is no financial support.

\section{References}

1. Handler MZ, Schwartz RA. Staphylococcal scalded skin syndrome: diagnosis and management in children and adults. J Eur Acad Dermatol Venereol 2014;28:1418. [CrossRef],

2. Mockenhaupt $M$, Idzko $M$, Grosber $M$, Schopf $E$, Norgauer J. Epidemiology of staphylococcal scalded skin syndrome in Germany. J Invest Dermatol 2005;124:700-3.'[CrossRef]

3. Scheinpflug K, Schalk E, Mohren M. Staphylococcal scalded skin syndrome in an adult patient with T-lymphoblastic non-Hodgkin's lymphoma. Onkologie 2008;31:616-9. "[CrossRef $]_{1}$

4. Hakim H, Flynn PM, Knapp KM, Srivastava DK, Gaur AH. Etiology and clinical course of febrile neutropenia in children with cancer. J Pediatr Hematol Oncol 2009;31:623!'[CrossRef]

5. Altinel E, Yarali N, Isik P, Ozkasap S, Bay A, Kara A, et al. Evaluation of febrile neutropenia in children with acute leukemia. Turkish J Pediatr Dis 2012;6:93-100.

6. Iwatsuki K, Yamasaki O, Morizane S, Oono T. Staphylococcal cutaneous infections: invasion, evasion and aggression. J Dermatol Sci 2006;42:203-14. [CrossRef].

7. Bukowski M, Wladyka B, Dubin G. Exfoliative toxins of Staphylococcus aureus. Toxins 2010;2:1148-65. [CrossRef]

8. Ladhani S, Joannou CL, Lochrie DP, Evans RW, Poston SM. Clinical, microbial, and biochemical aspects of the exfoliative toxins causing staphylococcal scalded-skin syndrome. Clin Microbiol Rev 1999;12:22442.'[CrossRef]"

9. Patel GK, Finlay AY. Staphylococcal scalded skin syndrome: diagnosis and management. Am J Clin Dermatol 2003;4:165-75!' [CrossRef]'

10. Aydin D, Alsbjorn B. Severe case of staphylococcal scalded skin syndrome in a 5-year-old child - case report. Clin Case Rep 2016;12:4169.'[CrossRef]"

11. Stanley JR, Amagai M. Pemphigus, bullous impetigo, and the staphylococcal scalded-skin syndrome. N Engl J Med 2006;355:180010. [CrossRef]

12. Frey $N$, Jossi J, Bodmer $M$, Bircher A, Jick SS, Meier CR, et al. The epidemiology of Stevens-Johnson syndrome and toxic epidermal necrolysis in the UK. J Invest Dermatol 2017;137:1240-7! [CrossRef]' 